\title{
Article
}

\section{Fair game? Journalists' experiences of online abuse}

\author{
Binns, Amy
}

Available at http://clok.uclan.ac.uk/15535/

Binns, Amy ORCID: 0000-0002-9173-3108 (2017) Fair game? Journalists' experiences of online abuse. Journal of Applied Journalism \& Media Studies, 6 (2). pp. 183-206. ISSN 2001-0818

It is advisable to refer to the publisher's version if you intend to cite from the work. http://dx.doi.org/10.1386/ajms.6.2.183_1

For more information about UCLan's research in this area go to http://www.uclan.ac.uk/researchgroups/ and search for < name of research Group>.

For information about Research generally at UCLan please go to http://www.uclan.ac.uk/research/

All outputs in CLoK are protected by Intellectual Property Rights law, including Copyright law. Copyright, IPR and Moral Rights for the works on this site are retained by the individual authors and/or other copyright owners. Terms and conditions for use of this material are defined in the policies page.

\section{CLoK}

Central Lancashire online Knowledge www.clok.uclan.ac.uk

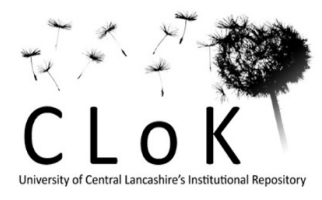




\section{Fair game? \\ Journalists' experiences of online abuse}

Online abuse of journalists through comments below articles or on Twitter is now ubiquitous. The tough-minded industry culture means it has generally been dismissed as unimportant, however high-profile cases of rape and bomb threats have given it greater significance. This research, based on a survey of 267 journalists and four detailed interviews, sought to establish what effect it had on them and their behaviour. Results showed women were more likely than men to report often receiving insults or threats, and had stronger emotional reactions to abuse. News reporters were more likely to report abuse than other sectors of the industry, and were more likely to report problems with online gangs. Many described their powerlessness when targeted by organised gangs. Some respondents described serious problems offline and online, including leaving jobs and self-censoring due to fear of abuse.

Keywords: journalists; online abuse; Twitter; self-censorship; online gangs; women in journalism

\section{Introduction}

\section{Journalists: Thick-skinned and Tough-minded}

Journalists have never been short of critics. Although some branches of the profession have, at times, gained respect for front line news, or even affection for community commitment, the green-ink brigade has always been present. Postbags have always contained denunciations of imagined political and financial motives, morals and literacy (Coren, 2011; Campen, 2014). However, prior to social media, filtering systems to some extent protected journalists. Firstly, letters to the editor were far fewer in number than the comments now received by newspapers (Drysdale, 2006). Many newspapers refused all anonymous letters as a matter of public policy, further affecting both the number and quality (Cox, 2006; Reader, 2006). Letters were generally opened by a newsdesk secretary, who removed the offensive or incoherent. The remainder went to the news editor or editor, who would make further selections based on their entertainment value for readers, authority (thus privileging certain groups), brevity and relevance (Wahl-Jorgensen, 2002). The few that raised serious queries, such as accusations of inaccuracy, were subject to discussion between the desk editor (a former reporter who understood working practices) and reporter. Social media and comments underneath stories have removed these filters while the very public nature of the abuse has added humiliation.

The rise in participatory journalism has been the subject of much research, but studies have usually been concerned about how the 'people formerly known as the audience' can improve quality, or democracy (Lowrey and Anderson, 2006; Singer, 2010; Karlsson, 2011). Other studies have looked at how audience participation is reshaping newsrooms and journalistic practice (Singer, 2010; Cook, 2014; Artwick, 2013). Offensive behaviour in comment threads or publications' online forums has long been an issue, and publications have sought solutions 
through moderation, registration, profanity filters, removing anonymity etc (Binns, 2012; Gsell, 2009; Niles, 2007; Uberoi Kelly et al, 2002). Reader (2012) suggested uncivil behaviour on anonymous threads is now so common it is becoming the cultural norm.

Despite all this research, the possibility of the outright, personal abuse of individual journalists online becoming a significant problem has not been anticipated or much studied. Writing in 2007, Deuze et al outlined case studies of participatory news that could provide a template for the industry, but though they acknowledged the professionals had had 'a rough ride' this was attributed to the journalists' "entrenched notions of professionalism, objectivity and carefully cultivated arrogance" rather than difficult behaviour by site users. The view that it is for the professionals to make concessions for the new participants without defining boundaries seems common. Journalism textbooks acknowledge the contribution of the audience and the need for journalists to engage, but rarely touch on direct abuse or threats (Carroll, 2010, tells moderators to demonstrate a thick skin but most writers do not mention it). Studies on the factors influencing journalists have also mostly focussed on political, economic and organisational influences (Hanitzch and Mellado, 2011; Hannitzch et al 2010; Vujnovic et al, 2010) rather than on this new, direct feedback.

It is only recent high profile cases of bomb and rape threats aimed at journalists (Batty, 2013; Hess, 2014) and at other high profile women such as feminist campaigner Caroline CriadoPerez, broadcaster and academic Mary Beard, and Olympic athlete Beth Tweddle (The Guardian, 2014; Cohen, 2014) that have brought attention to the issue, not all of it sympathetic (Pagels, 2013). A worrying report by Bartlett et al (2014) analysing two million tweets shows that journalists were the only category of public figures studied where women received more abuse than men, with female journalists and TV news presenters receiving three times as much abuse as their male counterparts. At a wider level, the International News Safety Institute (Barton and Storm, 2014) has also reported women in the media as facing wide ranging violence and harassment, including online.

Of course, journalists are not the only group that have faced these new kind of attacks. There has been much work on abuse issues faced by adolescents in particular (Davidson et al, 2011; Li, 2007; Wolak, Mitchell and Finkelhor, 2007), authors and others selling on Amazon (David and Pinch, 2005) and the wider public (Ronson, 2015). However, the journalism industry itself has its own entrenched culture which can be dismissive of both criticism and journalists who complain of criticism. Journalism was, and to some extent still is, maledominated (Society of Editors, 2014; Women's Media Center, 2014; Willnat and Weaver, 2014) with a macho image regardless of the sex of the reporter (Steiner, 2010; Ross and De Bruin, 2004, North, 2010). 'If you can't take the heat, get out of the newsroom' could well be a slogan for a profession that prides itself on toughness and black humour. Reporters and editors gained bragging rights through a refusal to submit to any authority but that of their own kind, whether political, commercial or just plain violent. This tough-mindedness had, and has, enormous value in terms of preserving the neutrality of the news, but may come at a cost of stress and staff turnover, particularly among women (Reinardy, 2009). It may also mean journalists are reluctant to admit to self-censorship. This is a known issue in terms of 'worthy but dull' stories and commercial pressures in the West (Pew Research Center, 2000; Kalven, 2010) and in less democratic countries (Hughes, 2013) but is only beginning to be understood in terms of anonymous online comments shaping news in democratic countries (Nielsen, 2014).

This research explores whether this type of abuse could exacerbate the issue of gender inequality in newsrooms, and lead to increased self-censorship. It also considers whether this 
abuse may result in an already thick-skinned culture becoming even more impervious to criticism due to less tough-minded journalists, male and female, leaving the profession.

\section{Research questions}

Although most publicity about serious abuse has been around women (Batty, 2013; Hess, 2014), I was concerned that the macho nature of newsrooms may hide the fact that men were also emotionally affected by the issue but were not able to publicly admit it. The research is also concerned with whether certain types of journalists were more likely to receive abuse.

Personal insults are likely to provoke a stronger reaction than insults about journalists' brands, so the research was also concerned with what kind of abuse different media workers receive.

RQ1: Which groups of journalists report receiving most abuse, and of what kind?

RQ2: What are their emotional reactions?

Preliminary research made clear that networked hostile groups were a significant problem, particularly on Twitter, in some cases leading to arrests (Boyle, 2014).

RQ3: Which groups of journalists are most likely to have a problem with online gangs, and in what way?

In order to build on good practice, we need to know how journalists are currently dealing with the problem, both in immediate practical terms, such as technical fixes to block users, and in the longer term, such as changing work practices or self-censorship.

RQ4: How do journalists deal with abusive messages in terms of immediate management of the problem?

RQ5: How does abuse affect journalists' behaviour in the longer term?

In addition to analysis of data, some comment boxes were included in the survey to allow respondents' voices to be heard.

\section{Methods}

The initial aim was to reach the widest possible range of journalists, including those who had not been subjected to online abuse, or who had received abuse but had not been distressed by it.

Initially, I hoped to be able to work with a media organisation in order to achieve this and avoid the issue of polling a self-selecting group, but although managers of several organisations were concerned about their staff and keen to explore this issue, mass emails from HR departments requesting survey responses went largely unanswered. This was not 
surprising given the extremely busy nature of most newsrooms, but it made clear that selfselection bias would be inevitable.

I therefore had to abandon hopes of reaching a truly representative group, but decided to make the survey more accessible by making it as short as possible and publicising it through industry contacts and well-read trade websites. In order to make it more attractive to as wide a group as possible, respondents were told they could see initial results when the survey was completed (but not comment boxes which could lead to people being identified).

The research aimed to provide a picture of how online abuse affects the industry, including who is most affected. This doesn't just mean who gets the most abuse, but also their emotional response. In these terms, and as respondents are self-reporting, the level of insults received was not measured in absolute terms ('more than once a week') but in terms of journalists' own assessment (never, sometimes, often). This also reflects respondents varying levels of public exposure, from local paper bylines, to regular on-screen appearances. University of Central Lancashire staff sent it to personal contacts in the industry, gaining a hundred responses in a week. The initial results were used to gain publicity through trade sites including Press Gazette, Hold the Front Page, Journalism.co.uk, closed LinkedIn groups for journalists and well-read industry blogs including Roy Greenslade and David Higgerson. It was also put out to as an @ message requesting retweets to targeted Twitter accounts including Women in Journalism. In all communications, we stressed that we were keen to hear from people who hadn't had problems as well as those who had.

Despite this, self-selection bias means data regarding percentages of journalists overall who experience abuse cannot be extrapolated. This data should be treated as qualitative, with numbers only serving to suggest trends. This research makes no claims that this survey of largely British journalists who chose to respond to this survey is representative of the industry as a whole. Rather, it aims to offer a qualitiative insight into journalists' responses to abuse.

The survey was closed after three weeks, 305 responses had been received. Of these, 38 defined themselves as student journalists or as not working in the media, these were discounted. No question was compulsory, so numbers may not add up to 267 . Early questions received more answers. Results were analysed and were the basis of four detailed interviews with senior professionals: a regional paper news editor, a national paper foreign editor, a national journalist and author, and a regional paper website manager. Three requested anonymity.

\section{Results}

RQ1: Which groups of journalist report receiving most abuse, and of what kind?

Respondents were asked how often they received various types of abuse: insults about their brand, insults about their work, personal insults, sexual insults, sexual threats, and other types of threats. For each of the six categories they could tick never, sometimes or often. Overall, reports of abuse online were high, in line with Kodellas et al's report on journalists' victimisation experiences (2014), though as this is a self-selecting group these figures can only suggest a trend. Overall, only 17 respondents (six per cent) said they had never experienced any kind of abuse online. 
Across all respondents, reported levels of insulting or threatening behaviour were similar between both sexes, which appears to contradict anecdotal evidence. Women were much more likely to receive sexual insults or threats, though men were marginally more likely to report receiving other threats. However, these numbers were being affected by the lower levels of abuse received by female features journalists compared to female news journalists. Most features journalists responding were female (24 out of 31).

Comparing the sexes within a role, women report more abuse. Comparing female and male news journalists, women were far more likely to say they often receive abuse across all categories. They were roughly twice as likely to say they often receive insults about their brand, work, or personal insults. This is in line with the findings of Bartlett et all (2014). They are far more likely to receive sexual insults ( $\mathrm{n}=44,38.64 \%$ sometimes, $4.55 \%$ often), compared to male news journalists ( $\mathrm{n}=45,6.67 \%$ sometimes, $0 \%$ often). Women also reported more sexual threats and similar levels of other threats (female news journalists, $\mathrm{n}=44,29.55 \%$ sometimes, $4.55 \%$ often; male news journalists $n=46,26.09 \%$ sometimes, $4.35 \%$ often).

Though the increased harrassment of women is in line with findings by Bartlett et all (2014) and Simmons' study of teenage girls (2011), the picture by other researchers is complex depending on how abuse and bullying is defined, as Erdur-Baker's comparison with traditional bullying showed (2010).

Comparing between roles showed other differences. Despite the robust nature of sports discussion on Twitter, male news journalists were more likely to report receiving insults about their brand and work, though sports journalists were slightly more likely to report personal insults, and receiving non-sexual threats (sports journalists, $\mathrm{n}=32$ : sometimes $35.48 \%$, often $3.23 \%$; male news journalists, $n=46$ : sometimes $26.09 \%$, often $4.35 \%$ ). Features journalists reported fewer problems than news or sports journalists.

Editors were slightly more likely than other journalists to report receiving insults about their brand and non-sexual threats and slightly less likely to report other kinds of abuse. Only eight per cent of editors reported sexual insults (compared to $43 \%$ of female news journalists) and none reported sexual threats. This lack of direct experience could affect their perception of the issue.

$R Q 1$ result. News journalists are the most likely to report personal abuse and abuse of their work. Women are more likely to report more abuse than men in the same role. Editors report more abuse of their brand.

\section{RQ2: What are their emotional reactions?}

Respondents were asked how they felt about reading abuse, and could tick never, sometimes or often in categories of upset, very upset, frightened/intimidated, angry. Reports of emotional reactions, particularly being upset and angry, were high, see Table 4 in the appendices for details. Out of 184 people who answered this question, only 12 people ticked the "never" box to all four questions (11 of these were male, one of these, a male news journalist who said he had never received abuse, also left the message 'What a lot of sad bollocks this is. Grow up you lot.'). 
Women's reactions to abusive behaviour are stronger across the board. Men are less likely to say they are upset, very upset, frightened/intimidated or angry, and much less likely to say they often react emotionally to abuse.

Women's reactions to abuse online have been explored by many researchers since the 1990s. Herring summarised a decade of research in 2003, detailing the aggressive tactics in online discussions "explicitly targeted at female participants", and their resulting tendency to fall silent or drop out of listserv groups. Seelhof documented the mocking and threatening of women journalists and bloggers through concerted online attacks in 2007, well before Web 2.0 and widespread broadband brought online participation to the masses. She listed many journalists, feminists and women's rights campaigners who had been driven offline by abuse, saying that they were ultimately silenced by freedom of speech.

Of those who said they sometimes or often felt frightened or intimidated, the largest group were news journalists (26 of 52 respondents), with the rest being spread across the remaining categories. They were more likely to be female (62 per cent compared to the total response rate of 45 per cent), and more likely to have received sexual insults or threats. One woman wrote: 'It is very scary that you do not know if they will take it further into real life. As a woman the sexual abuse is extremely outrageous and the more scary part.' Another woman wrote: 'Possibly as a result of Leveson journalists are considered fair game. You need to develop a thick skin and even then it's not enough to save you from sleepless nights. I live alone with my children, I worry that the people who abuse me online might take it further and come looking for me, I worry for my children's safety.'

A female education correspondent became a target when her story about cultural diversity in schools was picked up by a far-right group. Another story criticising a teacher's behaviour resulted in an onslaught. She wrote:

I'm pretty thick-skinned, but was subject to comments about my appearance and sex life on our newspaper's website, and then I began receiving emails from pupils at the school. I felt scared to open my emails for about a week, again, I locked down my Twitter account after someone commented that I was stupid and 'deserved a slap'. My colleagues thought it was hilarious, and sent a group email repeating some of the worst comments. It was only when I started crying at my desk that they realised how upset I was, and apologised..... I almost called in sick because I couldn't face opening my emails.

However, even non-threatening abuse can be a problem. A male news journalist wrote:

When I first suffered online abuse for what I had written it hit hard because the abuse was personal and took on an air of 'we know you'. It undermined my sense of authoritative knowledge on subjects I was well versed in and eventually ... I stopped writing completely to take on an editing role.

Several commented that the sheer volume was wearing. A male editor wrote: 'I've never been frightened or felt the need to change what I'm doing, but sometimes the abuse adds another layer of stress that we really don't need in this industry. I'm not sure if that's truly measurable, but it certainly has an impact.' Another respondent, who was leaving journalism, said: 'The criticism didn't make me feel unsure about my work, but it took more of my energy each day to deflect it.' 
This could be described as "emotional labour", a concept that is not widely recognised in the journalism profession, which tends towards the "male virtues" of objectivity, independence and detachment (Chambers et al, 2004). However, it is well understood in other areas. Shield and Wilkins (2009) discussed on-the-job abuse of nurses and negative outcomes including "the likelihood of intending to leave their jobs or even the nursing profession altogether". Yagil (2008) and Guerrier and Adib (2001) both discussed sexual and other forms of harrassment in the hotel and allied service industries. They found women, particularly in lower positions, were most at risk. The work of Guerrier and Adib in particular produced some striking parallels with journalism online, such as the fact that hotels are simultaneously private and public "a home from home - but, at the same time, guests are away from home and freed from some of the constraints of being at home”. This relates to website editors' desire to encourage users to identify with the magazine or newspaper as "theirs" and to feel the forums or comment sections "belong" to the users, whilst at the same time the users enjoy the privileges of anonymity and lack of responsibility that you might find renting a room in a big city hotel. Yagil's review of research showing that people in low level service jobs are particularly vulnerable to abuse may not seem relevant when considering journalists, many of whom have post-graduate qualifications, but her remarks about cleaners' and waitresses' "weak position in the labor market" with managers who are highly focussed "to keep customers from switching to a competing organisation" have relevance to many junior journalists whose jobs are constantly threatened by unpaid interns and whose managers' lives are dominated by print sales and website statistics.

$R Q 2$ result. Self-selection bias means these numbers cannot be extrapolated across the industry. Nevertheless, the high percentages of people reporting emotional reactions suggest this is not a rare response. Women are more likely to report strong reactions than men, and are more likely to say they are often upset or angry.

RQ3: Which groups of journalists are most likely to have a problem with online gangs, and in what way?

In answer to the question: Have you ever been conscious of gangs acting against you?

The most targeted group by gangs was news journalists. Surprisingly, it was rarely reported amongst sports journalists ( $n=29$ answering this question), 82.76 per cent (24) said they had never been conscious of being targeted by gangs and only 17.24 per cent (5) said it happened sometimes. It may be that the term "gangs" did not seem relevant to sports journalists, who may be used to dealing with large partisan groups of readers and so don't consider them as "gangs". Some researchers examining women's roles in sports journalism have also suggested that the sports section of the newsroom is even tougher than the rest, with a "locker room mentality” that breeds even thicker skins (Hardin and Shain, 2006; Mozisek, 2015).

Many journalists were conscious that some stories would cause trouble: 'God forbid you provoke the ire of Naomi Watts fans' said one. Several journalists mentioned organised attacks by politically motivated organisations, including the right-wing English Defence League and Scottish independence campaigners, and groups from Syria, Northern Ireland and Rwanda.

In comments, many people described the impossibility of dealing with a concerted attack. Traditional advice has been to engage with readers, raising the level of debate, but several described how difficult this was with a Hydra-headed monster: 
Mostly on Twitter - your @ replies to one person are retweeted, so you know that people are reading you out of context .... I am also targeted for attacks - "pile ons" when one person gives the signal. If you try to reply to any individual person in the pile-on, they usually retweet your reply, and provide a running commentary to their followers at the same time as talking to you. This makes you very out of control.

One blogger set up a page about his interactions with me and encouraged discussion btl [below the line] which led to a lot of comments by his readers on pieces I had written or edited (i.e. by others, which I found even harder to deal with).

Individuals who are linked to one community group will often attack ... with several individuals chiming in at once. Trying to answer any legitimate questions they have usually backfires, leading to more and more questioning. It's relentless.

One person who doesn't like what you've written tweets an insulting message, but then will tag in other people. In one of my experiences, this escalated from one person tweeting something like "here's that journalist, let him know what you think of him" to a death threat from someone else four days later... well-meaning people you don't know can make the abuse worse. You might take to ignoring the abusive tweets, only to find some stranger has sent an angry reply to the abuser.

These comments, and many others on the same subject, show journalists' frustration with the impossibility of trying to do their job - communicate and explain the news - whilst being continually undermined and baited by a gang consciously acting together.

The effects of some readers' bad behaviour on the delivery of the service as a whole is also mirrored in other service industries. Berry and Seiders (2008) discussed the effect dealing with a small number of "unfair customers" had on employees, who are increasingly stressed and put on the defensive as a result: "In effect, fair customers are penalized by the actions of unfair customers.” They specifically described "blamers", customers who play a co-producer role in many services (as the audience does by providing information, contacts, story feedback and ideas etc), but who never see themselves in any way responsible for the outcome.

In some cases, online abuse turned into offline problems, including threats made face-to-face. One journalist was targeted by a singer's fans after he wrote a story they considered insulting. The fans started a concerted campaign including death threats and emails to his employer. They opened email accounts in his name, then used them to set up offensive webpages asking for child pornography. His bank and paypal accounts were hacked around the same time. Another respondent had experienced a denial of service attack (in which a website is made unavailable to its intended users, sometimes by overloading the hosting server with traffic) by thousands of followers of a religion. Some respondents were concerned that the out-ofcontext retweeting could permanently affect their public image. One female journalist who was regularly targeted by feminist groups wrote:

One tweet is RTd then it becomes an established "fact" within the group that I am "a known ..." which makes it okay to send abusive messages. And it escalates as this remains an utterly unexamined "truth" about me until not only am I combatting the original lie but the constant "why hasn't she apologized after all this time?" There is a me that is not me that they promote and it's impossible to argue against. 
Other comments on the same lines show journalists struggling to maintain their reputations in the face of group attacks.

This issue of journalists' maintenance of their personal reputations online is starting to attract more attention from researchers. Lee (2014) referred to journalists' social media activities as a double-edged sword. He said social media makes journalists more personally likeable while making them appear less professional. This increased informality may also lead to further abuse, as Yagil described in service industries: "when the service role is performed in an environment of informality and lack of structure, the boundary between work and social interaction is easily blurred and can encourage customer misbehaviour”. Holton and Moyneux (2014) have described how journalists are forced to sacrifice a personal identity online, and struggle to balance their own relationships with their audience and sources, possibly forged when freelancing, with companies' requirements that they represent and promote the brand.

$R Q 3$ result. Again, news journalists are most likely to report problems with gangs. The many lengthy comments suggest this is a problem many are struggling to grapple with. Some stories are known to provoke violent reactions from members of the public. This issue can have huge effects on journalists' offline lives, as well as being extremely stressful. 
RQ4: How do journalists deal with abusive messages in terms of immediate management of the problem?

Respondents were asked: How have you dealt with abusive messages? Tick as many as apply.Table 1: Dealing with abuse by percentage.

\begin{tabular}{|l|l|}
\hline Answer Choices & $\begin{array}{l}\text { Responses } \\
(\mathrm{n}=197)\end{array}$ \\
\hline Deleting your own original post & 12.69 \\
\hline Blocking the user & 64.97 \\
\hline Asking colleagues to delete or block users & 12.69 \\
\hline Replying publicly & 57.36 \\
\hline Replying privately & 27.41 \\
\hline Asking someone else to reply & 9.64 \\
\hline Asking police to take action & 6.09 \\
\hline I never receive abuse & 12.18 \\
\hline
\end{tabular}

Comments were allowed for this question and 35 were received, of which 22 mentioned ignoring abuse, this should have been included in the multiple choices. Two respondents had phoned the abusers' employers, one had retweeted abuse so everyone could see it. One had reported abuse to Twitter. One woman received so many outraged comments asking if she had no shame, that she and her interns plastered them up in the office on a 'Wall of Shame'. But despite heroic attempts to laugh it off, she ultimately left her position and went into PR.

$R Q 4$ result. Most journalists take active steps to deal with abuse, most commonly blocking or replying publicly. 
RQ5: How does abuse affect journalists' behaviour in the longer term?

Respondents were asked: Have you ever changed your behaviour as a result of messages you have received? Tick as many as apply.

Table 2: Long-term effects by percentage.

\begin{tabular}{|c|c|c|c|}
\hline Answer choices & Men $n=42$ & $\begin{array}{l}\text { Women } \\
\mathrm{n}=45\end{array}$ & All $n=88$ \\
\hline Changed my profile picture & 16.67 & 28.89 & 22.73 \\
\hline $\begin{array}{l}\text { Deleted a profile or account and started a new } \\
\text { one }\end{array}$ & 9.52 & 6.67 & 7.95 \\
\hline Stopped using a platform & 16.67 & 13.33 & 15.91 \\
\hline $\begin{array}{l}\text { Stopped reading the comments under my } \\
\text { articles }\end{array}$ & 50.00 & 64.44 & 57.95 \\
\hline Changed the way I research or write articles & 28.57 & 17.78 & 22.73 \\
\hline Stopped following a story, or type of story & 16.67 & 13.33 & 14.77 \\
\hline Started looking for another job & 7.14 & 17.78 & 12.50 \\
\hline Left a job & 4.76 & 11.11 & 7.95 \\
\hline $\begin{array}{l}\text { Changed my behaviour offline, such as } \\
\text { walking home a different way }\end{array}$ & 11.90 & 15.56 & 13.64 \\
\hline
\end{tabular}

NOTE: The total number is one more than the numbers of men and women listed because no question was compulsory. One features journalist did not fill in whether male or female but still completed the rest of the survey. This question was on the last page and received far fewer responses.

The most significant result is the number of journalists who no longer read the comments under their articles. One added: 'I should clarify - I never started reading the comments. That way lies madness.' A male news journalist wrote: 'As a male, much of the abuse is pretty trivial - more along the lines of stupid playground stuff. Yet the sheer volume can be wearying. The problem is that there is sometimes gold hidden in comments. But you have to wade through the shit to reach it. I prefer not to work in sewers.'

This deliberate avoidance of comments due to abuse is a depressing reversal considering Anderson's 2011 claims about a new journalistic deference to the audience, when he stated as 
fact: "A new level of responsiveness to the agenda of the audience is becoming built into the DNA of contemporary news work." In the same year, Hedman and Djerf-Pierre found that younger journalists were the most likely to be enthusiastic activists for social media, but in the intervening years, has even this group become disillusioned? The issue of journalists no longer connecting with their audiences, echoes research by Meyer and Carey (2014), who found that journalists need to be involved in forums to encourage commenting, but the more comments a newspaper received, the more negatively the journalists see their audience.

At inception, it was believed the comments section would be a valuable tool for sourcing stories and engaging with readers. It seems many journalists have dropped engagement in this way. In addition, $16 \%$ have stopped using a platform. In comments, several journalists said they had at times stopped using Twitter to wait for abuse to die down.

Almost 23\% said they had changed the way they researched or wrote stories. This may be positive - one male sports journalist wrote:

You do take even more care when writing and researching articles to ensure your knowledge of a subject goes far beyond the remit of the piece you're writing about. Not that all of the information will go into an article, but it's sometimes helpful to arm yourself with information that's likely to be needed as / when abuse begins.

However, this may indicate a chilling effect on stories that could be a problem, especially combined with the $15 \%$ who have stopped following a story, or type of story. Comments from men and women were similar. Both sexes said they had taken steps to make finding them offline more difficult. One man said: 'I no longer post anything on any social media about places where I will be; concerts, holidays or anything. 1) I fear people will target me at those events. 2) I fear they will target my home while they know I am away.' Others commented on the difficulties between trying to engage with readers while preventing themselves being targeted. One wrote:

I think it is a real problem for regional journalists, who live in the community they write about. We are encouraged to be open and engaging on social media ... but there is a fine line between what I talk about on Twitter for fear of giving too much information away.

Of 88 respondents, 13 said they had stopped following a story or type of story. This number is too small to provide robust analysis, but the 13 were split between the major categories, with news journalists being the largest group. This appeared to be a last resort as they had all tried different kinds of action, with almost all having blocked users and tried replying publicly. More than half had tried replying privately and other methods of dealing with abuse. A male news journalist wrote: 'It is very difficult to return to subjects which led to adverse comments and insults. I find myself engaging in self-censorship.’

Journalistic self-censorship is not of course new - many researchers have commented on the difficulties journalists face in less democratic countries (Tong, 2009; Simons and Strovsky, 2006) and Seelhoff's work on women journalists and bloggers (2007) has already been mentioned above, but this silencing through commenting and insults in Western newsrooms seems new. In 2000, Kohut's examination of the reasons journalists self-censor did not even include abuse or fear as a category. 
$R Q 5$ result. The low response rate here makes it more difficult to be definite, but the percentages who are ceasing to engage may be of concern to managers. The numbers who have stopped following stories or left jobs will be explored further in the discussion section.

\section{Detailed interviews}

Most respondents who wrote comments in the survey focussed on their experiences of personal abuse. This was seen as less of an issue by the editors I interviewed, who, not surprisingly, had to deal most with abuse of the brand.

The web editor and news editor of a Northern British regional daily both said their biggest problem was racist commenting on stories. They have now stopped allowing comments on school picture stories to prevent racist comments about children. A story about a new mosque was swamped with comments, including people incorrectly accusing the paper of deliberately not reporting until the day before the planning meeting so residents wouldn't have a chance to stop the planning application. The news editor said:

They did not read the story just the headline...we just had to freeze the comments. The whole point of people being able to comment on the story disappears. There were one or two sensible comments which were overshadowed. It infuriates me.... We get people abusing us a lot: we are in bed with the council, we are in bed with the Muslims... The worst thing is if there's a crime and if we don't say what colour the offenders are it's assumed that they are Asian and we are not putting it on because they are Asian and it's political correctness gone mad.

The newspaper's policy is to allow criticism of the brand, but to delete criticisms of individual reporters. The news editor said the worst insults to reporters were on Facebook, which she could do little about. She thought this may be because Facebook viewers were more likely to be irritated by the stories "cluttering up their feed", unlike those reader who had chosen to visit the paper's own site. She said her reporters were thick-skinned and generally didn't look at comments, and that they were more likely to be angry than upset. The web editor said some of the more outrageous comments were laughed off or recycled in the newsroom. He said he did ban people and tried to deal reasonably with regular commenters, at one stage trying to educate them about racism. The web editor said gangs were a significant problem. One regular left-wing commenter was often a target:

There's definitely a pack mentality of racist idiots who are abusing anything Asian and he tries to defend them and they all rant on him... He constantly gets 50 minus thumbs [thumbs down on his remarks] because so many people are against him. He thinks someone's using scripts [automated coding] to rig it and he may be right.

The web editor said the paper was often hijacked by people who were clearly not part of the normal readership: 'What someone's done is posted a link to it on an EDL website and you get all the right wing idiots coming on.' The EDL is known for its grassroots activism and enthusiastic use of social media (Busher, 2013), to the extent that it can only be understood through its online, and particularly Facebook activity (Bartlett and Littler, 2011).

However, despite the problems both editors agreed they would never want to get rid of the ability to leave comments. The news editor said: 'Our print readership is getting older but for 
our younger audience, our web figures are really good. They are at least engaging with us so I do think it's important.'

A former foreign news editor for a global news organisation also said there were specific stories that provoked endless comments, particularly about Syria, Libya and the Ukraine. He said:

Russia employs quite a lot of trolls. You get countries who employ people to post comments on the end of articles slagging them off in order to soften them [the reporters] up... It becomes one more tactic of intimidation....Anything you write about Israel is going to get attacked by the pro-Israel lobby. Any correspondent going to Jerusalem knows they are likely to get that kind of stuff. You need a fairly thick skin to deal with it.... It's incredibly offensive.

These types of trolls may not be exactly as described by Buckels et al (2014), but have a more conscious objective than simple joy of trouble-making. In cases where there seemed to be a real threat, the news organisation would write to the embassies or the Foreign Office or Twitter. But despite these cases, he still felt the ability to comment and tweet provided huge opportunities for journalists to find out more, singling out the use of Twitter during the Arab Spring. Fast feedback on Twitter also allowed corrections to be made very quickly. He felt it was inevitable that most comments would be negative, as the silent majority of readers would rarely engage. He said: "The people who comment, I think they need to have a negative view. I think that's what motivates them."

However much abuse was received, he was confident that it would not affect the way stories were covered but he added: 'Ours is a big international organisation with lawyers and money. We are not a freelance. It's much easier to intimidate individuals or people who work on small blogs.'

Journalist and writer Nicholas Blincoe agreed that Israel was a real touchstone to many rightwing commenters. He has lived part-time in Bethlehem for many years and writes for the Guardian and Telegraph about Israeli-Palestinian affairs. He is a Palestinian sympathiser. He said most commenters were not really Guardian readers. He said: 'They are actually on the lookout for Israeli-Palestinian pieces to engage with. There are three issues that mobilise the right-wing blogosphere, to be ideologically sound: Israel/Palestine, climate change and gay marriage. They have become shibboleths.'

He said the pro-Israeli group tended to be more coherent than the opposition, because proPalestinian people tended to have a lot of different views and more nuanced ideas. 'The proIsraeli ones have a very narrow focus. They are much more like Beliebers than they are political commenters.'

Mr Blincoe said he had stopped reading the comments on his political pieces, though he still read comments on his work as an art critic. Sometimes he felt his status as a Palestinian supporter, though a minor part of his CV, overshadowed his other work. He found the abuse wearing and was sometimes tempted to stop writing about it, but he was strongly motivated by his interest in Palestine.

He followed the Guardian policy of engaging with readers on Comment is Free on the basis that if commenters realised they were dealing with a real person they would not be abusive and it would encourage civilised debate. He said: 
I took that on board. CIF felt to be combative and I was fairly combative. I realised the combative tone was self-defeating. I don't think it's an essentially combative form... I have moderated my tone so my pieces are reasonably grounded. It's got even more important to be as civilised and as level headed as possible. There's not room for more Richard Littlejohns. We need more civilisation.

\section{Discussion}

Of note was the amount of publicity and high response rate this research received, suggesting a consciousness within the industry of a significant problem.

The difficulties of dealing with abuse from a hostile public are well understood in other sectors, such as nursing, social work and hospitality, as "emotional labour". It is well known as a factor that can lead to highly qualified, valuable staff leaving these professions. It has not generally been considered in journalism, perhaps due to the profession's commitments to "masuline virtues" and pride in tough-mindedness, as discussed above. However, increased contact with an audience which can be hostile has clearly increased this emotional labour to a level where it should not be ignored.

One of the most concerning features is the level of self-censorship implied by the 15 per cent who said they had stopped following a story, or type of story, because of abuse. The numbers answering this question were small and were taken from a group probably disproportionately affected by abuse, but it was still surprising to find even one journalist admitting to dropping a story. This cuts to the heart of journalistic practice. Editorial independence from outside pressure is the basic ethos of most newsrooms. This self-censorship could be taken as an indicator of the seriousness of this issue.

Many respondents said they had changed the way they researched stories in the light of comments, and this may be a positive. They described being more careful in order to be able to deal with criticism better when their work was published. In detailed interviews, editors described how feedback on stories can help correct errors quickly. However, abusive behaviour may also undermine journalists’ credibility.

Neurater-Kessels (2011) described the abuse on British newspaper online comment threads as being a type of "face-attack" of the journalists, designed to imply a "lack of authority, credibility and trustworthiness with regard to their journalistic work". Several respondents also commented that they felt their hard-won reputations and public profiles were under attack, and that they were powerless to defend themselves against a concerted group assault on platforms such as Twitter. This is an issue for an industry which appears to be facing a decline in public trust (Kellner 2012), particularly in the light of the Leveson inquiry.

Though it is a problem generally, abuse appears to have a disproportionate effect on women. Due to self-reporting, it may be women do not receive more abuse. It may be they merely give it greater weight and so are more likely to remember and report it, but in a sense this is immaterial. The actual volume of abuse received may be less important than their reaction. A significant proportion of women said they often felt upset or angry. Although the abuse itself may be deleted and cognitively dismissed as unimportant, the emotions it generates may not be so easily disposed of. Several men and women, both in interview and in comments on 
the survey, said reading abuse added another layer of stress to what was already a stressful job. For a journalist already at the tipping point due to balancing work/life commitments, deadlines and sheer volume of work, the extra stress caused by negative feedback may be the straw that breaks the camel's back. One respondent, who was about to start work in a new sector, wrote: 'The criticism didn't make me feel unsure about my work, but it took more of my energy each day to deflect it.' These results showed 12 per cent had started looking for another job and eight per cent had left a job because of abuse. Although the numbers are small, there was a clear gender imbalance, with 18 per cent of women saying they had started looking for another job (seven per cent of men) and 11 per cent saying they had left a job (five per cent of men).

Despite the influx of women into journalism over many decades, the glass ceiling is still firmly in place (Wilnat and Weaver, 2014, Voss and Speere, 2014). At the Society of Editors, only three members of the 16-strong board are women. There are no women on the Society's Advisory Council, or female Fellows (Society of Editors, 2014). As Reinardy (2009) discussed, though women make up a large proportion of the workforce, they are less likely to be in management or editorial positions, less likely to be married or have children than male colleagues, and are on average younger. O’Brien (2014) also found they were more likely to leave the profession due to the way media work is structured, lack of networking opportunities, gender bias and other issues.

It is impossible for women to progress if they are lost to the profession early due to stress or other issues. The importance of equal voices and equal representation in positions of influence is generally agreed, and the increase of abuse of journalists is mitigating against positive change.

\section{Conclusion}

The title of this paper comes from one respondent's comment:

I've always found it extraordinary that journalists are still viewed, across all sections of society, as fair game for all forms of abuse, particularly online. I don't think employers do enough to help their journalists when they become victims of vicious and often sustained campaigns of hatred.

Most sectors of the industry have never been held in high regard, and trust in journalists appears to be declining (Kellner, 2012). Additionally, anyone in a position of authority, whether politician, headmaster or boss, is seen as fair game for ridicule and criticism. Readers may put journalists into this category - they have admin privileges on the site, they are paid for their opinions where the reader is not. But though they may be part of a powerful institution, they are still vulnerable as individuals.

It is difficult to know how much time and energy the profession should devote to this. Different publications and writers will have different needs. Some respondents said managers didn't seem to realise how damaging abuse on comments was to their brand. One respondent said expert contacts were very conscious of the comments, and may refuse to contribute to stories for fear of being damaged later in the comments. In terms of brand management, publications may not know what proportion of readers may use a site regularly without ever 
scrolling down to the comments, and so be unaware of their content. Others may see and ignore them.

In personal terms, some journalists see and dismiss abuse without being affected. Others deal with it by ignoring it - attempting to actively manage it may make the issue worse for this group. Some kinds of abuse, such as pile-ons in social media or out-of-context retweets, may be impossible to manage. Attempting to do so may just waste time and prolong the agony.

It may seem that journalists are merely getting a taste of their own medicine. For many years, some celebrities have complained about out-of-context quotes being endlessly recycled, about incorrect old stories being reprinted as background from uncorrected digital archives, and about the difficulties of answering questions when faced with a mob of reporters - all issues that are now repeated in the echo-chamber of Twitter and other platforms. This may explain why journalists get little sympathy from the public.

The problems of losing valuable, experienced talent from the industry apply across genders and professions. The newspaper industry, particularly in Britain, has long been regarded as being arrogant and impervious to criticism. If the industry cannot find a way of dealing with abuse online, or supporting journalists to deal with it, then it seems likely that the more receptive, morally sensitive journalists of both sexes will be the ones who leave the industry. These are the people the industry may need the most if it is to regain public trust and good standing.

\section{References}

Artwick, Claudette (2013) Reporters on Twitter. Digital Journalism 1(2), 212-228.

Bartlett, Jamie et al (2014) Social media is transforming how to study society. Demos. Available at http://www.demos.co.uk/publications/voxdigitas. Access date 19 December 2014.

Bartlett, Jamie and Littler, Mark (2011) Inside the EDL: Populist politi. Demos.

Barton, Alana, and Storm, Hannah (2014) Violence and Harassment Against Women in the News Media: A Global Picture. International News Safety Institute.

Batty, David (2013) Bomb threats made on Twitter to female journalists. The Guardian, 1 August http://www.theguardian.com/technology/2013/jul/31/bomb-threats-twitter-journalists. Access date 10 July 2014.

Berry, Leonard, and Seiders, Kathleen (2008) Serving Unfair Customers. Business Horizons 51: 29-37

Binns, A (2012) Don’t Feed the Trolls. Journalism Practice 6(4): 547-562.

Boyle, Darren (2014) Female journalist receives further sectarian abuse from fans of jailed racist Rangers podcaster. Press Gazette, 10 January 2014. 
Busher, Joel (2013) Grassroots activism in the English Defence League: Discourse and public (dis)order. In: Extreme Right Wing Political Violence and Terrorism. Continuum, pp. 65-84.

Cook, Clare (2014) Everyone or somebody? Assessing the impact of social media on newsroom organisational structures. Journal of the Association of Journalism Educators 3(1): $120-137$

Campen, Steve (2014) The Green Ink Brigade. 26 February, Creative Radio Partnership, http://thecreativeradiopartnership.blogspot.co.uk/2014/02/the-green-ink-brigade.html, access date 10 July 2014.

Carroll, Brian (2010) Writing for Digital Media. New York: Routledge.

Chambers, Deborah, Linda Steiner, and Carole Fleming (2004). Women and journalism. Psychology Press.Cohen, Claire (2014) Beth Tweddle's vile Twitter abuse: Women, it's time to shout back at trolls. The Telegraph, 22 January, http://www.telegraph.co.uk/women/womens-life/10589168/Vile-Twitter-abuse-BethTweddle-Women-its-time-to-shout-back-at-trolls.html, access date 12 July 2014.

Coren, Victoria (2011) Oh, for the days of green ink. The Observer, 30 January, http://www.theguardian.com/commentisfree/2011/jan/30/victoria-coren-homophobia-hatemail, access date 12 July 2014.

Cox, David (2006) Letters are best-read section of newspaper, Grassroots Editor, 47 (1):12

David, Shay, \& Pinch, Trevor (2005). Six degrees of reputation: The use and abuse of online review and recommendation systems. Cornell University. Available at http://papers.ssrn.com/sol3/papers.cfm?abstract_id=857505. Access date 18/03/2016

Davidson, J., Grove-Hills, J., Bifulco, A., Gottschalk, P., Caretti, V., Pham, T., \& Webster, S. (2011). Online abuse: Literature review and policy context. European Online Grooming Project.

Deuze, Mark, Bruns, Axel, Neuberger, Christop (2007) Preparing for an Age of Participatory News. Journalism Practice 1(3): 322-338.

Drysdale, Dick (2006) Letters are so important that I handle them myself, Grassroots Editor, 47 (1):13

Erdur-Baker, Ozgur (2010) Cyberbullying and its correlation to traditional bullying, gender and frequentand risky usage of internet-mediated communication tools, New Media and Society 12(1) 109-125

Erjavec, Karmen, and Poler-Kovacic, Melita, (2013) Abuse of Online Participatory Journalism in Slovenia: Offensive Comments under News Items. Medijska istraživanja 19(2): 55-74.

Gsell, L, (2009) Comments Anonymous. American Journalism Review Feb/March 2009 
The Guardian, (2014) Two jailed for Twitter abuse of feminist campaigner. 24 January, http://www.theguardian.com/uk-news/2014/jan/24/two-jailed-twitter-abuse-feministcampaigner, access date 10 July 2014.

Hanitzsch, Thomas, et al (2010) Modeling perceived influences on journalism: evidence from a cross-national survey of journalists. Journalism \& Mass Communication Quarterly 87(1): $5-22$.

Hanitzsch, Thomas, and Mellado, Claudia (2011) What shapes the news around the world? How journalists in 18 countries perceive influences on their work. The International Journal of Press/Politics 16(3): 404-426.

Hardin, Marie, and Shain, Stacie (2006) Feeling Much Smaller than You Know You Are. Critical Studies in Media Communication. 23(4): 322-338

Herring, Susan C. "Gender and power in online communication." The handbook of language and gender (2003): 202-228.

Hess, Amanda (2014) Why Women Aren't Welcome on the Internet. Pacific Standard magazine, Jan/Feb 2014, http://www.psmag.com/navigation/health-and-behavior/womenarent-welcome-internet-72170/, access date 10 July 2014.

Hughes, Kirsty (2013) Global View. Index on Censorship, 26 March, http://www.indexoncensorship.org/2013/03/global-view/, access date 13 July 2014

Kalven, Jamie (2010) Bite the hand that feeds. 25 May, Columbia Journalism Review, http://www.cjr.org/feature/bite_the_hand_that_feeds.php?page=all, access date 13 July 2014

Kellner, Peter (2012) The problem of trust. YouGov 13 November http://yougov.co.uk/news/2012/11/13/problem-trust/, access date 14 July 2014

Karlsson, Michael (2011) The immediacy of online news, the visibility of journalistic processes and a restructuring of journalistic authority. Journalism 12(3): 279-295.

Kodellas, Spyridon, Papsastavrou, Niki, Giannakoulpoulos, Andreas, Koutsompolis, Dimitris (2014) Journalists' victimization experiences and fear of crime at the workplace: Results of a questionnaire survey from Greece and Cyprus. European Journal of Communication 29(4): 480-494.

Kohut, Andrew (2000). Self-censorship: Counting the ways. Columbia Journalism Review, 39(1), 42-43. Retrieved from http://search.proquest.com/docview/230351761?accountid=17233

Li, Qing., 2007. 'New bottle but old wine’, Computers in Human Behaviour 23, Elsevier.

Lowrey, Wilson, and Anderson, William (2006) The Journalist Behind the Curtain: Participatory Functions on the Internet and their Impact on Perceptions of the Work of Journalism. Journal of Computer-Mediated Communication 10(3).

Mozisek, Korryn (2015) No Girls Allowed! Female Reporters as Threats to the Male Domain of Sports. Journal of Sports Media 10(2): 17-29 
Neurauter-Kessels, Manuela (2011) Im/Polite Reader Responses on British Online News Sites. Journal of Politeness Research 7:187-214

Nielsen, Carolyn (2014) Coproduction or cohabitation: Are anonymous online comments on newspaper websites shaping news content? New Media and Society 16(3) 470-487.

Niles, Robert. (2007) Take a fresh look at your site's posting rules. OJR: The Online Journalism Review October 9

North, Louise (2007) Just a little bit of cheeky ribaldry: Newsroom discourses on sexual harrassment. Feminist Media Studies 7(1) 81-96.

O’Brien, Anne (2014) 'Men own television': why women leave media work. Media Culture and Society, 36 (8) 1207-1218.Pagels, Jim (2013) Death threats on Twitter are meaningless. You should ignore them. Slate, 13 October 2013, http://www.slate.com/blogs/future_tense/2013/10/30/twitter_death_threats_are_meaningless you_should_ignore them.html, access date 13 July 2014.

Pew Research Center (2000) Self Censorship: how often and why. http://www.peoplepress.org/2000/04/30/self-censorship-how-often-and-why/, access date 13 July 2014.

Reader, Bill (2012) Free Press vs Free Speech? The Rhetoric of 'Civility' in Regard to Anonymous Online Comments. Journalism and Mass Communication Quarterly 89: 495.

Reader, Bill (2006) Current Issues Regarding Letters to the Editor. Grassroots Editor 47(1):15

Ronson, Jon (2015) So You’ve Been Publicly Shamed. Picador, London.

Ross, Karen, and de Bruin, Marjan (2004) Gender and newsroom cultures: identities at work Cresskill, N.J.: Hampton Press.

Seelhoff, Cheryl Lindsey (2007) A Chilling Effect: The Oppression and Silencing of Women Journalits and Bloggers Worldwide. Off Our Backs 37(1):18-21

Simmons, Rachel, (2011). 'Odd Girl Out’, second edition, Houghton Mifflin Harcourt, p133.

Simons Greg, Strovsky Dmitry. (2006) Censorship in contemporary Russian journalism in the age of the war against terrorism: A historical perspective European Journal of Communication, 21 (2) , pp. 189-211.

Singer, Jane (2010) Quality Control. Journalism Practice 4(2) 127-142.

Society of Editors, Who's Who? http://www.societyofeditors.co.uk/, access date 10 July 2014. Steiner, Linda (2010) Handbook of Journalism Studies ed Wahl-Jorgensen, Karin, and Hanitzch, Thomas, London: Routledge.

Tong, Jingrong (2009) Press self-censorship in China: a case study in the transformation of discourse Discourse \& Society September 20:593-612, doi:10.1177/0957926509106412 
Uberoi Kelly, Sean, Sung, Christopher and Farnham, Shelly (2002) Designing for improved social responsibility, user participation and content in on-line communities. Proceedings of the SIGCHI conference on Human factors in computing systems: Changing our world, changing ourselves, Minneapolis, Minnesota, USA.

Vujnovic, Marina, et al (2010) Exploring the Political-Economic Factors of Participatory Journalism. Journalism Practice 4(3) 285-296.

Wahl-Jorgensen, Karin. "Understanding the conditions for public discourse: four rules for selecting letters to the editor." Journalism Studies 3.1 (2002): 69-81.

Willnat, Lars, and Weaver, David (2014) The American Journalist in the Digital Age Bloomington, IN: School of Journalism, Indiana.

Wolak, Janis, Kimberly J. Mitchell, and David Finkelhor. (2007) "Does online harassment constitute bullying? An exploration of online harassment by known peers and online-only contacts." Journal of adolescent health 41.6: S51-S58.

Woodzicka, Julie A., and Marianne LaFrance. "Real versus imagined gender harassment." Journal of Social Issues 57.1 (2001): 15-30.

Women's Media Center (2014) The Status of Women in the U.S. Media 2014. Available at http://www.womensmediacenter.com/pages/2014-statistics. Access date 19 December 2014.

Appendices

Spreadsheets of survey results will be available in the [redacted for anonymous refereeing] online repository.

Table 3: Types of abuse reported by percentage.

\begin{tabular}{|l|l|l|l|l|l|l|l|}
\hline & \multicolumn{4}{|c|}{ Insults } & \multicolumn{3}{c|}{ Threats } \\
\cline { 2 - 8 } & Brand & Work & Personal & Sexual & & Sexual & Other \\
\hline All respondents sometimes & 38.58 & 47.94 & 33.33 & 12.36 & 3.75 & 22.1 \\
\hline All respondents often & 20.97 & 11.99 & 9.36 & 1.12 & 0 & 3 \\
\hline All respondents total & $\mathbf{5 9 . 5 5}$ & $\mathbf{5 9 . 9 3}$ & $\mathbf{4 2 . 6 9}$ & $\mathbf{1 3 . 4 8}$ & $\mathbf{3 . 7 5}$ & $\mathbf{2 5 . 1}$ \\
\hline Sports journalists sometimes & 50 & 65.63 & 51.61 & 3.23 & 0 & 35.48 \\
\hline Sports journalists often & 15.63 & 3.13 & 9.68 & 0 & 0 & 3.23 \\
\hline Sports journalists total & $\mathbf{6 5 . 6 3}$ & $\mathbf{6 8 . 7 6}$ & $\mathbf{6 1 . 2 9}$ & $\mathbf{3 . 2 3}$ & $\mathbf{0}$ & $\mathbf{3 8 . 7 1}$ \\
\hline
\end{tabular}




\begin{tabular}{|l|l|l|l|l|l|l|l|}
\hline Male news journalists sometimes & 56.25 & 68 & 46 & 6.67 & 4.55 & 26.09 \\
\hline Male news journalists often & 25 & 14 & 10 & 0 & 0 & 4.35 \\
\hline Male news journalists total & $\mathbf{8 1 . 2 5}$ & $\mathbf{8 2}$ & $\mathbf{5 6}$ & $\mathbf{6 . 6 7}$ & $\mathbf{4 . 5 5}$ & $\mathbf{3 0 . 4 4}$ \\
\hline Female news journalists sometimes & 45.45 & 55.32 & 45.65 & 38.64 & 9.3 & 29.55 \\
\hline Female news journalists often & 38.64 & 27.66 & 17.39 & 4.55 & 0 & 4.55 \\
\hline Female news journalists total & $\mathbf{8 4 . 0 9}$ & $\mathbf{8 2 . 9 8}$ & $\mathbf{6 3 . 0 4}$ & $\mathbf{4 3 . 1 9}$ & $\mathbf{9 . 3}$ & $\mathbf{3 4 . 1}$ \\
\hline Female features journalists sometimes & 41.18 & 61.11 & 38.89 & 26.67 & 13.33 & 18.75 \\
\hline Female features journalists often & 17.65 & 16.67 & 16.67 & 0 & 0 & 0 \\
\hline Female features journalists total & $\mathbf{5 8 . 8 3}$ & $\mathbf{7 7 . 7 8}$ & $\mathbf{5 5 . 5 6}$ & $\mathbf{2 6 . 6 7}$ & $\mathbf{1 3 . 3 3}$ & $\mathbf{1 8 . 7 5}$ \\
\hline
\end{tabular}

Table 4: Emotional reactions by percentage.

\begin{tabular}{|l|l|l|l|l|l|l|}
\hline & $\begin{array}{l}\text { Men } \\
\text { sometimes }\end{array}$ & $\begin{array}{l}\text { Men } \\
\text { often }\end{array}$ & $\begin{array}{l}\text { Men } \\
\text { total }\end{array}$ & $\begin{array}{l}\text { Women } \\
\text { sometimes }\end{array}$ & $\begin{array}{l}\text { Women } \\
\text { often }\end{array}$ & $\begin{array}{l}\text { Women } \\
\text { total }\end{array}$ \\
\hline Upset & 62.5 & 11.54 & $\mathbf{7 4 . 0 4}$ & 68.35 & 26.58 & $\mathbf{9 4 . 9 3}$ \\
\hline Very upset & 28 & 5 & $\mathbf{3 3}$ & 51.43 & 14.29 & $\mathbf{6 5 . 7 2}$ \\
\hline Frightened/intimated & 17.82 & 1.98 & $\mathbf{1 9 . 8}$ & 39.44 & 5.63 & $\mathbf{4 5 . 0 7}$ \\
\hline Angry & 52.88 & 27.88 & $\mathbf{8 0 . 7 6}$ & 53.25 & 41.56 & $\mathbf{9 4 . 7 5}$ \\
\hline
\end{tabular}

Table 5: Experiences of gangs.

\begin{tabular}{|l|l|l|l|l|}
\hline & $\begin{array}{l}\text { News } \\
\text { journalists } \\
\mathrm{n}=89\end{array}$ & Men $\mathrm{n}=106$ & Women $\mathrm{n}=85$ & All $\mathrm{n}=192$ \\
\hline Never & 61.8 & 64.15 & 64.71 & 64.58 \\
\hline Sometimes & 28.09 & 29.25 & 29.41 & 29.17 \\
\hline
\end{tabular}


